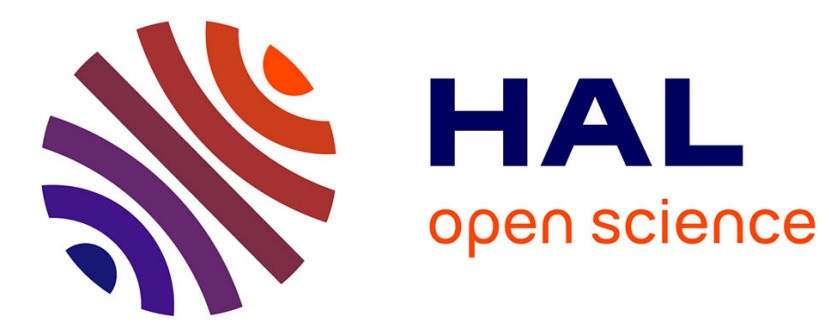

\title{
Valence States of Copper and Cation Distribution in Submicron Copper Ferrite Spinels CuxFe3-xO4(0 $\leq \mathrm{x} \leq 1)$
}

E. Kester, B. Gillot, P. Perriat, C. Villette, Ph. Tailhades, A. Rousset

\section{To cite this version:}

E. Kester, B. Gillot, P. Perriat, C. Villette, Ph. Tailhades, et al.. Valence States of Copper and Cation Distribution in Submicron Copper Ferrite Spinels CuxFe3-xO4 $(0 \leq x \leq 1)$. Journal de Physique IV Proceedings, 1997, 07 (C1), pp.C1-261-C1-262. 10.1051/jp4:19971101 . jpa-00254722

\section{HAL Id: jpa-00254722 https://hal.science/jpa-00254722}

Submitted on 1 Jan 1997

HAL is a multi-disciplinary open access archive for the deposit and dissemination of scientific research documents, whether they are published or not. The documents may come from teaching and research institutions in France or abroad, or from public or private research centers.
L'archive ouverte pluridisciplinaire HAL, est destinée au dépôt et à la diffusion de documents scientifiques de niveau recherche, publiés ou non, émanant des établissements d'enseignement et de recherche français ou étrangers, des laboratoires publics ou privés. 


\title{
Valence States of Copper and Cation Distribution in Submicron Copper Ferrite Spinels $\mathrm{Cu}_{x} \mathrm{Fe}_{3-x} \mathrm{O}_{4}(0 \leq x \leq 1)$
}

\author{
E. Kester, B. Gillot, P. Perriat, C. Villette*, Ph. Tailhades* and A. Rousset*
}

Laboratoire de Recherche sur la Réactivité des Solides, UMR 5613, Faculté des Sciences Mirande, BP, 138, 21004 Dijon cedex, France

* Laboratoire de Chimie des Matériaux Inorganiques, URA 1311 du CNRS, Université Paul Sabatier, 118 route de Narbonne, 31062 Toulouse cedex, France

\begin{abstract}
Valence states studies of copper and iron ions and their cation distribution on both octahedral (B) and tetrahedral (A) sites on the spinel structure of submicron copper-substituted magnetites, $\mathrm{Cu}_{\mathrm{x}} \mathrm{Fe} 3-\mathrm{x} \mathrm{O}_{4} \quad(0 \leq \mathrm{x} \leq 1)$ which are oxidized in cation deficient spinels $\mathrm{Ca}_{\mathrm{X}} \mathrm{Fe}_{3-\mathrm{x}} \mathrm{O}_{4+\delta}(0 \leq \delta \leq 0.5)$ have been performed by TG, DTG, FT-IR and XPS when the copper content determine the number of oxidizable cations $1-x=\left(\mathrm{Fe}^{2+}+\mathrm{Cu}^{+}\right)$per mole of ferrite. It was demonstrated that $\mathrm{Fe}^{2+}$ and $\mathrm{Cu}^{+}$ions are oxidized into $\mathrm{Fe}^{3+}$ and $\mathrm{Cu}^{2+}$ ions below $300^{\circ} \mathrm{C}$ and that the availability to diffuse could be envisaged as follows : Cu${ }_{\mathrm{B}}^{+}$ $\left(130^{\circ} \mathrm{C}\right)<\mathrm{Fe}_{\mathrm{B}}^{2+}\left(185^{\circ} \mathrm{C}\right)<\mathrm{Cu}_{\mathrm{A}}^{+}\left(240^{\circ} \mathrm{C}\right)$. For high copper content $(\mathrm{x} \geq 0.4)$, the presence of additional interstitial $\mathrm{Cu}^{+}$ions in tetrahedral sites has also been found
\end{abstract}

\section{INTRODUCTION}

The cation distribution in submicron $\mathrm{Cu}_{\mathrm{X}} \mathrm{Fe}_{3}-\mathrm{O}_{4}$ spinels $(0 \leq \mathrm{x} \leq 1)$ and cation deficient spinels obtained by oxidation at low temperature has been investigated by thermogravimetry (TG and DTG), , FT-IR spectroscopy and XPS. We describe the combined use of these techniques to evaluate the valence and copper ion distribution and its dependence on temperature and oxygen pressure. These spinels were prepared by a "chimie douce" method via decomposition of mixed oxalate precursors as reported in ref. [1], the average cristallite size being close to $35 \mathrm{~nm}$.

\section{RESULTS AND DISCUSSION}

\subsection{Study by thermogravimetry and cation distribution}

It has been previously established that the oxidation temperature of $B$-sites $M^{n+}$ ions is lower than that of $A$-sites $M^{n+}$ ions because of the weaker ionic bonding of the B-sites as compared with the stronger A-sites covalent bonds [2]. In this context an analysis by thermogravimetry on the basis of a redox-type mechanism of copper has been intented to differentiate the oxidation temperature of each oxidizable cation. Figure 1 (curve a) shows the DTG curve for a sample with $\mathrm{x}=0.32$. Three oxidations should be implicated with this temperature resolution. The intense peak at $200^{\circ} \mathrm{C}$ can be attributed to the $\mathrm{B}$-site Fe $2+$ ion oxidation, this oxidation temperature having been largely demonstrated elsewhere [3].The peak at $290^{\circ} \mathrm{C}$ and the shoulder at $150^{\circ} \mathrm{C}$ represent the oxidation of copper ions. The comparison with $\mathrm{Cu}_{\mathrm{x}} \mathrm{Mn}_{3-\mathrm{x}} \mathrm{O}_{4}$ spinel containing $\mathrm{A}$-site $\mathrm{Cu}^{+}$ions [4] permit us to attribute in the copper ferrites the peak appearing at $290^{\circ} \mathrm{C}$ to the oxidation of $\mathrm{A}$-site $\mathrm{Cu}^{+}$ions. The shoulder appearing at about $150^{\circ} \mathrm{C}$ was as a matter of fact due to the oxidation of $\mathrm{B}$-site $\mathrm{Cu}^{+}$ions, a proposition that is supported by one larger cationoxygen distance [2].

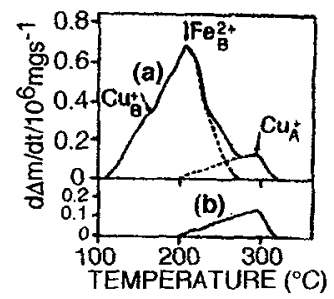

Figure 1: (a) global oxidation curve and desummation peaks, (b) curve showing the disappearance of the first and second peaks 
In order to propose a cation distribution, a quantitative analysis of cations from the determination of oxidation peak areas has been carried out. The profile of the peak attributed to the oxidation of $\mathrm{Cu}^{+}$ion on $\mathrm{A}$-sites, first determined by desummation (Fig. 1, curve a), has been confirmed by DTG after selective oxidation in isothermal conditions at $140^{\circ} \mathrm{C}$. for $24 \mathrm{~h}^{\circ} \mathrm{Cu}^{+}$and $\mathrm{Fe}^{2+}$ ins on B-sites. After this procedure, the reoxidation on heating in $\mathrm{O}_{2}$ corresponding to the curve b represents only the oxidation of $\mathrm{Cu}^{+}$ions on $\mathrm{A}$-sites. For differentiate and evaluate quantitatively the oxidation peak areas of these two cations, the $\mathrm{Cu}^{+}$ions concentration on B-sites has been determined from oxygen loss due to the unoxidability of copper ions at low oxygen pressure which is the basis of the oxygen analysis. At $27 \mathrm{~Pa}$ and above, overall cations $\mathrm{Cu}_{\mathrm{B}}^{+} \mathrm{Fe}_{\mathrm{B}}^{2+}$ and $\mathrm{Cu}_{\mathrm{A}}^{+}$are totally oxidized as confirmed by the latice constant value found to be the lowest. The heating curves for 9 and 6 Pa reveal that the copper ions ate oxygen pressure dependent. Thereby, the magnitude of the mass-gain difference between 27 Pa and lower partial pressures of oxygen corresponds to cations which have not been oxidized.The difference in oxygen content reaches a plateau region in the interval $180<\mathrm{T}<205^{\circ} \mathrm{C}$ which indicates that for an oxygen pressure of $9 \mathrm{~Pa}$, the Fe $\mathrm{Fe}^{2+}$ ions have been completely oxidized. We can thus attribute the magnitude of this difference to the amount of $\mathrm{Cu}_{\mathrm{B}}^{+}+\mathrm{Cu}_{\mathrm{A}}^{+}$ions initially present in the spinel lattice. With an oxygen pressure of $6 \mathrm{~Pa}$, the plateau region was absent and a significant $B$ site $\mathrm{Fe}^{2+}$ ions amount remains after this treatment as supported by the important difference of mass gain above $230^{\circ} \mathrm{C}$. The cation distribution obeys the formula:

$\left(\mathrm{Cu}_{\alpha \mathrm{x}}^{+} \mathrm{Fe}_{1-\alpha \mathrm{x}}^{3+}\right)_{\mathrm{A}} \quad\left(\mathrm{Cu}_{(1-\alpha-\beta) \mathrm{x}}^{2+} \mathrm{Cu}_{\beta \mathrm{x}}^{+} \mathrm{Fe}_{1+(2 \alpha+\beta) \mathrm{x}}^{3+} \mathrm{Fe}_{1-(1+\alpha+\beta) \mathrm{x}}^{2+}\right)_{\mathrm{B}} \mathrm{O}_{4}^{2-}$ with $\alpha=0.50$ and $\beta=0.20$ for $\mathrm{x}=0.32$.

However, this distribution cannot be generalized, the $\alpha$ and $\beta$ coefficients being dependent on the copper content and thermal treatment which leads, for samples quenched from temperatures higher that $600^{\circ} \mathrm{C}$, to deficient oxygen spinels $\mathrm{Cu}_{\mathrm{X}} \mathrm{Fe} 3-\mathrm{x} \mathrm{O}_{4-\delta}$. For these non-stoichiometric phases, the oxidation reveals a larger mass gain than that calculated with 1 -x per mole of ferrite. This is ascribed to the presence, of both additional interstitial $\mathrm{Cu}^{+}$ions and octahedral $\mathrm{Fe}^{2+}$ ions at sites nomally occupied in the original deficient spinel. For deficient oxygen spinel, $\mathrm{CuFe}_{2} \mathrm{O}_{4-\delta}(\mathrm{x}=1)$, the observed mass gain is duc to the oxidation of $\mathrm{Cu}^{+}$ions interstitial. In all cases, the oxidation temperature for $\mathrm{Cu}^{+}$ions interstitial associated with the spinel structure is higher than that for $\mathrm{Cu}^{+}$ions in A site implying that intercalated copper ions are also located in A sites.

\subsection{Distribution in cation deficient spinels}

When the copper is substituted for iron in $\mathrm{Fe}_{3} \mathrm{O}_{4}$, the FT-IR spectrum exibits two broad absorption bands near 353 and 562 $\mathrm{cm}^{-1}$, typical of a "chemical" disorder resulting from $\mathrm{Fi}^{2+}$ and $\mathrm{Fe}^{3+}$ ions on equivalent sites. The Cu 2 p3/2 spectrum shows an intense peak at $932 \mathrm{eV}$. It has a large value of the full width at half maximum (FWHM=3.7 eV) compared with those of oxidized samples, that seems to be a strong evidence for the presence of $\mathrm{Cu}$ in different binding states. As a matter of fact, $\mathrm{Cu}$ $2 \mathrm{p} 3 / 2$ peak contains several signals whose the binding energies have the following values : $930.7 \mathrm{eV}, 932 \mathrm{eV}$ and $934 \mathrm{eV}$. In comparison with other results [5], the peak at $934 \mathrm{eV}$ in the spectrum can be interpreted as belonging to $\mathrm{Cu}^{2+}$ on $\mathrm{B}$-sites, the peak at $932 \mathrm{eV}$ to $\mathrm{Cu}^{+}$on A-sites and at $930.7 \mathrm{eV}$ to $\mathrm{Cu}^{+}$on B-sites.

The FTIR spectra of oxidized samples under non-isothermal conditions $\left(\mathrm{PO} 2=4 \times 10^{3} \mathrm{~Pa}, 2^{\circ} \mathrm{C} \mathrm{min}-1\right.$ ) and quenched from various temperatures exhibit, in the temperature range $150-450^{\circ} \mathrm{C}$ when cation deficient spinels are formed, a large number of absorption bands, those being well-resolved for samples oxidized at 250,300 and $340^{\circ} \mathrm{C}$. For these three temperatures, the similarity with the FTIR spectrum of ordered $y$ - $\mathrm{Fe}_{2} \mathrm{O}_{3}[6]$, both in the position and number (at least 20) of absorption bands permits us to postulate the same type of order between vacancies and cations on B-sites, i.e. a $\square /$ cation ratio of $1 / 5$. Indeed, the complete oxidation of $\mathrm{Cu}_{\mathrm{B}}^{+}, \mathrm{Fe}_{\mathrm{B}}^{2+}$, and $\mathrm{Cu}_{\mathrm{A}}^{+}$leads to a maximum of vacancies. For the same composition, the spinel oxidized at 180 and $450^{\circ} \mathrm{C}$ shows the disappearance of some absorption bands, especially in the region $500-150 \mathrm{~cm}^{-1}$. The observed difference may be reasonably explained by a lower number of vacancies resulting from a partial oxidation of cations. At $180^{\circ} \mathrm{C}$, only $\mathrm{Cu}_{\mathrm{B}}^{+}$and a part of $\mathrm{Fe}_{\mathrm{B}}^{2+}$ ions are oxidized, that strongly reduces the number of vacancies and thereby only a partial ordering occurs [6]. On the other hand, at $450^{\circ} \mathrm{C}$ the decrease of vacancy content is related to reduction process occurring at this temperature.

The spectrum of $\mathrm{Cu} 2 \mathrm{p} 3 / 2$ of a sample oxidized at $180^{\circ} \mathrm{C}$ shows a $\mathrm{Cu} 2 \mathrm{p} 3 / 2$ signal with a small value of the FWHM (3.1 eV) consequently to the absence of $\mathrm{Cu}_{B}^{+}$in the structure. Curve fitting yields only two signals caused by $\mathrm{Cu}^{+}$on $\mathrm{A}-\mathrm{sites}$ $(932.3 \mathrm{eV})$ and $\mathrm{Cu}^{2+}$ on $\mathrm{B}$-sites $(934.3 \mathrm{eV})$. With increasing temperature more and more $\mathrm{Cu}$ ions are placed as $\mathrm{Cu}^{2+}$ on $\mathrm{B}-\mathrm{sites}^{2}$ and at $300^{\circ} \mathrm{C}$, where the mass gain is maximum, the signal is solely caused by $\mathrm{Cu}^{2+}$ ions on these sites .The existence of an intense satellite peak at $944 \mathrm{eV}$ in the spectrum clearly proves the presence of $\mathrm{Cu}^{2+}$ ions. For the reduction temperature domain $\left(350-480^{\circ} \mathrm{C}\right)$ where the spinel structure was maintained, $\mathrm{Cu}^{2+}$ is partly reduced and the signal of $\mathrm{Cu}^{+}$on $\mathrm{A}-$ site again appears.

\section{References}

[1] Villette C., Tailhades P. and Rousset A., C.R. Acad. Sci., Paris, 316 série II (1993) 1717-1721.

[2] Gillot B., J. Solid State Chem., 113 (1994) 163-168.

[3] Gillot B. and Rousset A., J. Solid Stare Chem., 65 (1986) 322-329

[4] Gillot B., Kharroubi M., Metz R., Legros R. and Rousset A., J. Solid State Chem., 91 (1991) 375-386

[5] D'Huysser A., Lercbours-Hannooyer B., Lenglet M. and Bonnelle J.P., J. Solid State Chem., 39 (1981) 246-257

[6] Gillot B., Vibrationel Spectroscopy, 6 (1994) 127-148. 